\title{
José Ortega y Gasset y La deshumanización del arte José Ortega y Gasset and La deshumanización del arte
}

\author{
Constanza Nieto Yusta*
}

\section{RESUMEN ABSTRACT}

El ensayo que José Ortega y Gasset publicaba en 1925, La deshumanización del arte, hacía su aparición en el contexto del desarrollo de la vanguardia artística española. La lectura que el filósofo realizó de la problemática existente entre el arte nuevo y su recepción polémica por parte del público se muestra hoy en día de una gran actualidad. En el análisis de José Ortega y Gasset entran en juego algunos de los factores decisivos en la gestación del arte del siglo xx: la abstracción, la ironía, el juego y la importancia de la recepción pública.

PALABRAS CLAVE

Deshumanización en arte-AbstracciónDistanciamiento-ironía-juego-público.
José Ortega y Gasset's essay La deshumanización del arte, published in 1925, appeared in the context of the Spanish artistic avant-garde. The interpretation of the Spanish philosopher about the relation between the contemporary art and its public controversial reception, is a subject of great importance today. The analysis of José Ortega y Gasset introduces most of basic concepts in the origin and development of contemporary art of the 20th century: the abstraction, the irony and the game and audience's importance.

El ensayo La deshumanización del arte hacía su aparición en 1925, año en el que se celebró en el Palacio del Retiro de Madrid la Primera Exposición de la Sociedad de los Artistas Ibéricos en la que participaron artistas como Rafael Barradas, Alberto Sánchez, Salvador Dalí, Ángel Ferrant, José Gutiérrez Solana, Benjamín Pa-

* Departamento de Historia de la UNED. E-mail: cnietoy@geo.uned.es 
lencia o Ucelay entre otros muchos. La muestra, fundamental para la gestación de La deshumanización en el arte, estuvo acompañada de la publicación de un catálogo y de una serie de conferencias en las que participó Ortega y de las que nos queda a modo de testimonio el texto El arte en presente y en pretérito ${ }^{1}$, fue un acontecimiento decisivo para el ulterior desarrollo de la vanguardia en España y derivó en la fundación de la Sociedad de Artistas Ibéricos en 1931, formación que hasta 1936 impulsó y organizó numerosas iniciativas relacionadas con el arte contemporáneo tanto en España como en capitales europeas tan relevantes como Paris y Copenhague.

1925 fue un año decisivo para lo que John Crispin denomina «Generaciones de $1925 »^{2}$. En España, Marinero en tierra de Rafael Alberti y Versos humanos de Gerardo Diego reciben el Premio Nacional de Literatura; Manuel de Falla compone Concierto para clavicémbalo, se estrena en Sevilla el Retablo de Manuel de Falla y Guillermo de Torre publica Literaturas europeas de vanguardia, «una especie de biblia», según palabras de Alejo Carpentier ${ }^{3}$, para el conocimiento en nuestro país de la vanguardia europea como un movimiento de carácter histórico. Asimismo, en 1925, se inaugura en París la Exposición Internacional de Artes Decorativas, de gran influjo para los arquitectos y artistas españoles; se publica El realismo mágico de Franz Roh y, recordemos, había pasado tan sólo un año de la aparición del Primer Manifiesto surrealista de André Breton.

La presencia y participación de Ortega en la muestra «ibérica» evidencia el contacto que el filósofo tenía con el ámbito de la creación, vinculación que puede encontrarse desde el mismo comienzo de su trayectoria y que se evidencia en numerosas publicaciones ${ }^{4}$. La herencia fenomenológica, procedente de su conoci-

${ }^{1}$ ORTEGA Y GASSET, José, Obras completas, Madrid, Fundación José Ortega y Gasset-Taurus, 2005, tomo III, págs. 909-916.

${ }^{2}$ CRISPIN, John, La estética de las generaciones de 1925, Valencia, Pre-Textos, 2002.

${ }^{3}$ Cita recogida en BONET, Juan Manuel, Diccionario de las vanguardias en España. 1907-1936, Madrid, Alianza, 1995, pág. 595.

${ }^{4}$ Solamente entre 1902, año en que comienza su producción, y 1925, fecha en que publica La deshumanización del arte, podemos encontrar reflexiones dedicadas a diversos ámbitos de la cultura y la creación artística, tanto nacional como internacional. De la ingente producción de artículos realizada estos años cabe destacar «A Ramón del Valle-Inclán» (Faro de Vigo, agosto 1902), «La conservación de la cultura» (Faro, marzo 1908), «¿Una exposición Zuloaga?» (El Imparcial, abril 1910), «Arte de este mundo y del otro» (El Imparcial, julio-agosto 1911), «Una visita a Zuloaga» (La Prensa, febrero 1912), «Los versos de Antonio Machado» (julio 1912), «La estética de El enano Gregorio el Botero» (1916), «La Gioconda» (1916), «Diálogo sobre arte nuevo» (El Sol, octubre 1924), «Sobre el punto de vista en las artes" (Revista de Occidente, 1924); y aquellos publicados en El Espectador de entre los que pueden mencionarse «Tres cuadros del vino (Tiziano, Poussin y Velázquez)» (1911), «Musicalia» (1921), «Los hermanos Zubiaurre» (1921) o «Meditación del marco»(1921).

A este mismo período pertenecen algunas de las obras de mayor envergadura producidas por el pensador acerca del arte: Meditaciones del Quijote (1914), Ensayo de estética a manera de prólogo (1914) e Ideas sobre la novela, ésta última aparecida el mismo año de la publicación del ensayo del que parte este estudio.

Para una información más detallada véase ORTEGA Y GASSET, Obras completas, 2005, tomos I-III. 
miento de Hegel y, principalmente, de aquel a quien siempre consideró su gran maestro, Edmund Husserl, es apreciable en la mayor parte de los textos del pensador. Aunque en los escritos dedicados a la política ${ }^{5}$, la relación con la Dialéctica y el «espíritu de la historia» hegelianos queda más patente que en los textos de carácter estético, en ambos tipos de reflexiones, por el alto grado de conceptualización en que se sustentan, podemos encontrar los mismos intereses y preocupaciones. Así, en los escritos sobre arte, los análisis de los elementos formales de la creación artística quedan en un segundo plano frente a las reflexiones de carácter abstracto y trascendental desarrolladas a partir de ellas. Semejante explicación podría satisfacer las numerosas objeciones lanzadas contra el supuesto desconocimiento que Ortega evidenciaba en su ensayo acerca del panorama artístico contemporáneo - por aquellos años en verdadera ebullición en toda Europa-, desvinculación que no parece del todo clara ${ }^{6}$ y que, no obstante, podría justificarse acudiendo al contexto del arte español, al margen por completo del resto de Europa, durante las primeras décadas del siglo XX.

No es nuestra intención analizar en el presente estudio una polémica que aún sigue abierta, sino abordar los aspectos que el autor señala como fundamentales para la deshumanización del arte contemporáneo y que, en tanto que reflexiones generales, se mantienen intemporales, actuales para su posible aplicación en las lecturas que aún siguen inspirando ochenta años después de su aparición.

Pasemos a examinar detenidamente cuál es el concepto de deshumanización del arte planteado por Ortega y Gasset en su ensayo, lectura necesaria para establecer el origen de las nuevas interpretaciones del concepto planteadas en este estudio así como las deudas que mantiene con su fuente de inspiración. El méto-

\footnotetext{
${ }^{5}$ Nacido en una familia muy vinculada a la prensa y al ámbito político (su padre fue el José Ortega y Munilla, escritor que ejerció una importante labor periodística como director de El Imparcial), Ortega y Gasset dirige la mayor parte de sus escritos a la disección y crítica sociopolítica. De la ingente producción de este tipo de textos destacamos, por el interés que tienen para nuestro estudio y por la futura mención que de ellos haremos en el mismo, «Imperialismo y democracia» (El Imparcial, enero 1910), "Socialismo y aristocracia» (El Socialista, mayo 1913); «Democracia morbosa» (1917), «El genio de la guerra y la guerra alemana» (1917), «Sobre el fascismo» (1921), todos publicados en El Espectador, España invertebrada. Bosquejos de algunos pensamientos históricos (1922), El tema de nuestro tiempo (1923), «Los alemanes y lo infrahumano» (La Nación, agosto 1924) y Las Atlántidas (1924). De las obras posteriores a 1925 señalaremos únicamente «La interpretación bélica de la historia» (El Espectador VI, 1927), Mirabeau o el político (1927)«El origen deportivo del Estado» (El Espectador VII, 1930), «Socialización del hombre» (El Espectador VIII, 1934) y La rebelión de las masas (1930-1947).

Para una información más detallada, remitimos de nuevo a las Obras completas, tomos I-III.

${ }^{6}$ A lo largo del ensayo encontramos numerosas referencias a figuras de importancia capital en la génesis y desarrollo artístico del siglo xx: Ortega menciona a Stéphane Mallarmé, Charles Baudelaire, Claude Debussy, el Ultraísmo, Ramón Gómez de la Serna, Pablo Picasso, Luigi Pirandello, el Dadaísmo... Para una mayor información del Ultraísmo, corriente de gran interés para Ortega, vid. FUENTES FLORIDO, Francisco, Poesías y Poética del Ultraísmo, Barcelona, Editorial Mitre, 1989.
} 
do de análisis escogido pretende extraer las ideas que quedan englobadas bajo la denominación genérica de deshumanización del arte a lo largo de toda su exposición. El objetivo es mostrar su importancia como nociones históricas, sociales y políticas así como las tensiones resultantes de la profunda relación entre ellas, revelando en el proceso su conexión con Meditación de la técnica (1933) y La rebelión de las masas (1947). Estas obras plantearán la necesidad de remontarnos al siglo XVIII, punto de partida tanto del concepto general de la deshumanización del arte como de todas las cuestiones en él implícitas y que en el presente apartado trataremos de analizar. Es necesario señalar ya en el inicio de este estudio que mientras Ortega habla de la deshumanización del arte, nosotros abordaremos cómo se traduce la deshumanización en el arte, ya sea como ideología social, política o científica así como tema formal desde los comienzos de la Edad Contemporánea hasta la primera mitad del siglo xx.

\section{DISTANCIAMIENTO DE LA NUEVA MIRADA CREADORA: REALIDAD “CONTEMPLADA», METÁFORA, IRONÍA Y JUEGO}

Todo el «arte nuevo» o «arte joven» ${ }^{7}$ posee un leitmotiv o una idea de base a partir de la cual construye sus propuestas estéticas, no importa lo diferentes que éstas sean una vez materializadas. Esta idea o complejo de ideas es la deshumanización, término que en el ensayo de Ortega se refiere al proceso mediante el cual el arte se despoja de todos sus vínculos con la realidad humana. Aunque en la enumeración que hace Ortega de las principales tendencias que recorren las diferentes propuestas artísticas contemporáneas ${ }^{8}$, la deshumanización figura como una más en el listado-eso sí, encabezando el cartel-, todas las cuestiones se remiten al concepto que da título al texto, son su explicación, su emanación lógica. Semejante vinculación se hace patente al abordar las reflexiones fenomenológicas que constituyen, si no la mayor parte del texto, la fundamental para su comprensión.

${ }^{7}$ Expresiones presentes en los ya mencionados «Diálogo sobre arte nuevo» y El arte en presente $y$ en pretérito ( vid. notas 1 y 2) pero que en La deshumanización del arte se refieren exclusivamente a las propuestas artísticas surgidas a partir de 1905. Obviamente, Ortega establece esta fecha como punto de partida del «arte nuevo» en base a la exposición celebrada precisamente ese año en el Salón de Otoño de París, en la que el escándalo suscitado por las obras de sus participantes - Henri Matisse y todos aquellos que a partir de entonces pasarían a llamarse fauvistas - inauguraba el comienzo de las vanguardias artísticas en Europa.

${ }^{8}$ El pensador señala que el arte nuevo «Tiende: $1 .^{\circ}$, a la deshumanización del arte; $2 .{ }^{\circ}$, a evitar las formas vivas; $3 .^{\circ}$, a hacer que la obra de arte no sea sino obra de arte; $4 .^{\circ}$, a considerar el arte como juego, y nada más; $5 .^{\circ}$, a una esencial ironía; $6 .^{\circ}$, a eludir toda falsedad, y, por tanto, a una escrupulosa realización. En fin, $7 .^{\circ}$, el arte, según los artistas jóvenes, es una cosa sin trascendencia alguna.» (ORTEGA Y GASSET, José, La deshumanización del arte y otros ensayos de estética, Madrid, Austral, 2004, pág. 57) 
Puesto que la fenomenología es el estudio de lo que se aparece (los fenómenos), el arte es uno de los objetos de su interés; de ahí que no sea la primera vez que Ortega emplea sus armas para aproximarse a él. En «Sobre el punto de vista en las artes ${ }^{9}$, artículo aparecido justo un año antes, el autor interpreta la historia del arte occidental a partir del papel jugado por el sentido de la vista en la aprehensión del objeto artístico en tanto fenómeno aparecido a un sujeto. Este artículo es de especial interés al plantear que los intereses del artista, y, por tanto, la mirada de los futuros contempladores de sus obras, han evolucionado en el tiempo hacia una mayor abstracción, progreso vinculado a los distintos puntos de vista adoptados a lo largo de la historia en la representación de los fenómenos. «Primero se pintan cosas; luego, sensaciones; por último, ideas. Esto quiere decir que la atención del artista ha comenzado fijándose en la realidad externa; luego, en lo subjetivo; por último, en lo intrasubjetivo. Estas tres estaciones son tres puntos que se hallan en una misma línea» ${ }^{10}$. La primera "estación» está representada por Giotto y los flamencos, los «pintores de cosas» fundamentales del siglo xv; la segunda, referente al inmenso periodo comprendido entre $1600 \mathrm{y}$ 1900 , por «pintores de sensaciones» como Caravaggio (pintor de la luz), Velázquez (pintor del aire) o los impresionistas (pintores del mismo acto de ver). La tercera corresponde al siglo xx, el siglo de los «pintores de las ideas», el punto de llegada de este progresivo alejamiento de la realidad material que es la historia del arte $^{11}$ y que tiene su homólogo en el cada vez más avanzado campo de las ciencias.

Pero ¿cómo explica Ortega la posibilidad de desvinculación del artista del mundo que habita, - de lo que él denomina la realidad «vivida»12- y la aún más impensable capacidad de traducirlo después a sus creaciones?

La deshumanización del arte viene a completar esta lectura esbozada un año antes: los creadores del arte nuevo dotan a sus obras de una estética deshumanizada al distanciarse radicalmente de la realidad «vivida», de los hombres y su existencia cotidiana (los objetos, espacios, seres vivos, seres inorgánicos...): es este distanciamiento en la mirada el que les permite dar el salto desde la realidad "vivida» hacia la realidad "contemplada»; es en este ámbito abstracto, ficticio en el sentido de opuesto al real, desde donde el artista -al modo del psicólogo respecto a su paciente- accede al territorio del arte puro. Al estar desvinculado por

${ }^{9}$ Op. cit., págs. 175-194.

${ }^{10}$ Op. cit., pág. 192.

11 «El cuadro, renunciando a emular la realidad, se convertiría en lo que auténticamente es: un cuadro-una irrealidad (...) De pintar las cosas se ha pasado a pintar las ideas: el artista se ha cegado para el mundo exterior y ha vuelto la pupila hacia los paisajes internos y subjetivos.» Op. cit., pág. 79.

${ }^{12}$ Op. cit., pág. 60. 
completo del ámbito de las cosas, el artista realiza arte por el arte, «arte artístico», «iconoclasia»13. Las cosas ya no son cosas, los cuerpos dejan de ser cuerpos: ya no quedan imágenes-calco del mundo.

Este es el sentido que Ortega otorga al concepto de deshumanización; no habla de deshumanización en el arte sino de deshumanización del arte en tanto que las creaciones a las que se refiere muestran un total desapego a todo lo propio de este mundo en su interés por el ascenso — casi al modo platónico- al mundo de la Creación como idea abstracta ${ }^{14}$.

Los medios empleados por los creadores de «arte joven» para deshumanizar sus obras son numerosos, pero todos ellos parten del conocimiento de la tradición artística y sus componentes para, inmediatamente después, alejarse radicalmente de ellos. El «arte nuevo» se recrea en la destrucción del «arte viejo», es decir, de toda la evolución artística de la humanidad: «El placer estético para el artista nuevo emana de ese triunfo sobre lo humano; por eso es preciso concretar la victoria y presentar en cada caso la víctima estrangulada» ${ }^{15}$.

La elección de la metáfora, en tanto «instinto que induce al hombre a evitar realidades ${ }^{16}$ es el mejor ejemplo de ello, aunque no el único ni el más efectivo. El recurso metafórico, presente en la poesía y las artes plásticas desde los orígenes de la creación por las posibilidades de abstracción y ascensión que ofrece ${ }^{17}$, es empleado de forma ligeramente distinta a la tradicional; pues si bien anteriormente la metáfora se dedicaba a exaltar y ornamentar la realidad «vivida», con los creadores del arte nuevo pasa a ser empleada como un instrumento deshumanizador, un «arma lírica», que «se revuelve contra las cosas naturales y las vulnera o asesina» ${ }^{18}$. El resultado es la ascensión y la creación de nuevos mundos deshumanizados en un estilo que Ortega denomina "Suprarrealismo" ${ }^{19}$ y que vio su comienzo en las artes con el papel de Claude Debussy en la música y de Stéphane Mallarmé en la poesía.

${ }^{13}$ Nombre del segundo y del décimo apartado del ensayo, respectivamente. Op. cit., págs. 52 y 80.

${ }^{14}$ En «Arte de este mundo y del otro» (ORTEGA Y GASSET, José, Obras completas, 2005, tomo I, págs. 434-450), Ortega comparaba el paso del Románico al Gótico en términos de ascensión o trascendencia: mientras el arte románico manifiesta un claro apego a lo terrenal y a la grávido, el arte gótico se libera del peso para elevar sus creaciones y dotarlas de ingravidez y carácter etéreo. Las resonancias del pensamiento platónico son obvias, asimismo en la cita registrada en Nota 11.

15 ORTEGA Y GASSET, José, La deshumanización del arte y otros ensayos de estética, Madrid, Austral, 2004, pág. 65.

${ }^{16}$ Op. cit., pág. 74.

${ }_{17}$ Ortega está pensando en manifestaciones artísticas como las producidas durante la Prehistoria, el Cristianismo e, incluso, en aquellas pertenecientes a culturas exóticas. Op. cit., págs. 80, 83 y 84 .

${ }^{18}$ Op. cit., pág. 75.

19 Op. cit., pág. 76. 
En contraposición, otro de los medios escogidos para deshumanización por los creadores de arte «nuevo», es el «Infrarrealismo» ${ }^{20}$. En este caso, la deshumanización se acomete a partir de una realidad «vivida» que se contempla desde un punto de vista inusual: aquel que nos aproxima con una mirada «microscópica» a los detalles no percibidos cotidianamente ${ }^{21}$. Este cambio de perspectiva en la aprehensión del mundo invierte, y por tanto, destruye y supera, el modo de representación tradicional. El mismo proceso de inversión de los valores puede apreciarse en el siguiente medio deshumanizador del arte señalado por Ortega.

Nos referimos a la utilización de la equivocidad por parte del arte contemporáneo. Ortega afirma «que el arte nuevo es un fenómeno de índole equívoca»²2, en gran medida a causa del contexto sociopolítico en que ha nacido pero que en última instancia responde a las tensiones a partir de las cuales se estructura la Historia. ${ }^{23}$ Pero una aproximación a los significados semánticos del calificativo muestra sus conexiones con uno de los conceptos fundamentales en el ensayo de Ortega y prácticamente condición sine qua non del arte contemporáneo: la ironía. Equívoco (Del latín aequivocus; aequus, igual, y vocare, llamar) queda recogido en el Diccionario de la Real Academia Española como la «palabra cuya significación conviene a diferentes cosas», es decir, aquello "que puede entenderse o interpretarse en varios sentidos, o dar ocasión a juicios diversos». Ortega califica al arte «nuevo» de equívoco en dos sentidos: por un lado, por la contradicción que supone querer generar formas artísticas desde el más pleno rechazo al Arte como tradición, institución y legado histórico; por otro, por el empleo de la ironía como una de sus principales armas en la consecución de semejante alejamiento. Puesto que por ironía se entiende una «burla fina y disimulada», basada generalmente en «dar a entender lo contrario de lo que se dice» ${ }^{24}$, la equivocidad constituiría tanto su punto de partida como su intención final.

\footnotetext{
${ }^{20}$ Ibidem.

${ }^{21}$ Como máximos ejemplos de Infrarrealismo, Ortega cita a Marcel Proust, James Joyce y Ramón Gómez de la Serna. Ibidem.

${ }^{22}$ Op. cit., pág. 85.

${ }^{23}$ La interpretación dialéctica hegeliana de la historia (Tesis-Antítesis-Síntesis) presente en prácticamente toda parte de la trayectoria del pensador español, también es empleada en sus lecturas del arte. Ortega explica el paso del arte «viejo» (Tesis) al arte «nuevo» (Antítesis) así como su triunfo (Síntesis) en base a la ironía con que éste asimila - y aprovecha en su favor - la equivocidad o contradicción que constituye el querer hacer arte desde el rechazo del mismo. «En vez de reírse de alguien o algo determinado — sin víctima no hay comedia—, el arte nuevo ridiculiza el arte. [...] Nunca demuestra el arte mejor su mágico don como en esta burla de sí mismo. Porque al hacer el ademán de aniquilarse a sí propio sigue siendo arte, y por una maravillosa dialéctica, su negación es su conservación y triunfo»(Op. cit., pág. 87).

${ }^{24}$ Según queda recogido en el Diccionario de la Real Academia de la Lengua Española.
} 
Los creadores del arte «nuevo» se instalan en el territorio de la ironía, categoría estética presente desde el siglo anterior ${ }^{25}$ pero que en las manos de los artistas contemporáneos ve renovadas sus posibilidades. Pues si bien en sus orígenes la ironía se materializaba en los temas representados ${ }^{26}$, en el siglo Xx pasa a ser la actitud desde la cual se abordará la creación artística. Los artistas contemporáneos emplean la burla, la broma, la farsa, para acometer su rechazo a la Tradición y para introducir la actitud lúdica, el juego, en todo lo concerniente a los planteamientos artísticos. Esta nueva perspectiva adoptada por el homo ludens ${ }^{27}$ que es ahora el artista contemporáneo explica su concepción del arte como «una cosa sin trascendencia»28; aunque existentes, las reglas del juego que es ahora la creación no son sino un acuerdo voluntario que por su esencia lúdica despojan tanto al objeto artístico y a todo lo que le concierne de cualquier seriedad o protocolo. La vida ya es demasiado ceremoniosa como para reproducir su solemnidad en la vía de escape que es el arte» ${ }^{29}$.

Es interesante señalar, a modo de conclusión, y por lo conveniente que resulta para nuestro estudio, que de entre todos los ejemplos de movimientos y artistas que Ortega escoge para ilustrar su ensayo, es el Dadaísmo el de mayor importancia por sintetizar en sus propuestas todos los rasgos que el filósofo considera deshumanizadores del arte. Su rechazo a la tradición, que en este caso estaba representada no sólo por el legado artístico, sino también por una política y por una clase social burguesa responsable de las guerras mundiales que azotarían Europa; su alejamiento de la realidad «vivida» en la poesía sonora, basada en la utilización de las palabras completamente desvinculadas de su significado y significante ortodoxos; y, el carácter lúdico e ironía en todas sus propuestas, encaminadas a des-

${ }^{25}$ Ortega establece en los románticos August Wilhelm y Friedrich Schlegel el momento histórico de la irrupción de la ironía como categoría estética (ORTEGA Y GASSET, José, La deshumanización del arte y otros ensayos de estética, Madrid, Austral, 2004, pág. 87).

${ }^{26}$ El siglo XIX será el siglo de la ironía por excelencia, encontrando una buena prueba de ello en la proliferación masiva de la caricatura como género artístico desde el cual se ejercía la sátira social y política más descarnada. Aunque tiene evidentes precedentes en el siglo XVIII, como, por ejemplo, en la serie de grabados Los Caprichos de Francisco de Goya, mencionamos este fenómeno por tener un papel relevante para nuestro ulterior estudio de la época del Romanticismo.

${ }^{27}$ Fue Johan Huizinga quien, al definir la naturaleza humana en base al juego, a su espíritu lúdico, posibilitaba nuevas lecturas de un hombre que, además de la denominación genérica que lo clasificaba en el mundo como ser racional (homo sapiens), estaba principalmente caracterizado como homo faber o ser que fabrica/trabaja desde el establecimiento definitivo del trabajo asalariado como medio de subsistencia. Posteriores lecturas, como la realizada por Marshall McLuhan en su ya clásico Galaxia Gutenberg: génesis del «homo typographicus, definirán al hombre en base a su relación con los descubrimientos tecnológicos más significativos de la Historia.

${ }_{28}$ Op. cit., pág. 88.

29 «Ser artista es no tomar en serio al hombre tan serio que somos cuando no somos artistas. [...] Si cabe decir que el arte salva al hombre, es sólo porque le salva de la seriedad de la vida y suscita en él inesperada puericia.» (Op. cit., págs. 87 y 89). 
truir la trascendencia que había acompañado a la institución Arte desde sus orígenes, convierten a este istmo, en el cual el autómata jugó un papel fundamental, en el paradigma de lo que Ortega entiende por deshumanización del arte. Asimismo, jugará un papel fundamental en nuestro ulterior estudio de la deshumanización en el arte de la primera mitad de siglo a partir de la figura del autómata. Pero para comprender el hilo conductor de nuestro discurso aún nos queda por abordar el concepto más importante tanto en el ensayo de Ortega como en el presente estudio: el papel del público en la problemática deshumanizadora.

\section{EL PÚBLICO: CAUSA Y EFECTO DE LA DESHUMANIZACIÓN DEL ARTE}

El público, entendido como el «conjunto de las personas que participan de unas mismas aficiones o con preferencia concurren a un determinado lugar", así como el «conjunto de las personas reunidas en determinado lugar para asistir a un espectáculo o con otro fin semejante ${ }^{30}$, no surgió como tal hasta el siglo XVIII. Con la aparición y desarrollo de los Salones en Francia, se produjo la «primera forma de democratización de la recepción de las obras de arte» ${ }^{31}$, desapareciendo su anterior relegación al ámbito privado de las minorías adineradas a quienes se reducía exclusivamente su adquisición y contemplación. El arte se convertía en un espectáculo para el grueso de la población y constituía, de este modo, un fenómeno sociológico que consecuentemente se vio acompañado del nacimiento del juicio estético o gusto y de la crítica de arte. Al introducir en escena al público, Ortega ya apunta desde el mismo comienzo del ensayo, la importancia del factor social, cultural y, como veremos más adelante, político, en la génesis de un nuevo arte que al ser impopular no logra la aceptación por parte de la inmensa mayoría de sus receptores y que, en consecuencia, se deshumaniza al alejarse de los intereses de buena parte de unos consumidores ajenos a la nueva sensibilidad estética.

En lo que Ortega entiende por deshumanización del arte se encuentra el origen de la escisión en la relación entre el público y la obra de arte, o, por decirlo con palabras del pensador español, de la impopularidad y antipopularidad que rodea a las propuestas creativas contemporáneas. Ortega caracteriza ontológicamente el arte

${ }^{30}$ Tal y como queda recogida la voz «público» en el Diccionario de la Real Academia de la Lengua Española.

${ }^{31}$ BOZAL, Valeriano, "Orígenes de la estética moderna" en Historia de las ideas estéticas y de las teorías artísticas contemporáneas, Madrid, La Balsa de la Medusa, 2000, vol. I, pág. 22. Para un estudio más detallado de los Salones véase BAUDELAIRE, Charles, Salones y otros escritos sobre arte, Madrid, La Balsa de la Medusa, 1999. 
nuevo en estos dos sentidos: mientras que por impopular entiende el no ser grato a la multitud $-y$, por tanto, se refiere al papel jugado por el receptor en el diálogo que resulta de la contemplación estética-, por antipopular apunta al hecho de no querer ser grato a la multitud- es decir, a la voluntad del emisor, o en este caso, del artista ${ }^{32}$. Esta reciprocidad basada en el rechazo del público como estación de ida y vuelta en la relación del creador con el espectador es una de las constantes del arte contemporáneo desde sus más tempranas apariciones ${ }^{33}$.

Las causas de la impopularidad y antipopularidad del arte «nuevo» se hallan en sus mismos planteamientos y medios de expresión artísticos. El alejamiento de la realidad «vivida» o de cualquier referencia a la vida cotidiana en pos de una mayor abstracción o arte puro; el carácter lúdico, irónico y de broma que acompaña a todas las «nuevas» manifestaciones creadoras en su rechazo de la tradición, de la autoridad y trascendencia que a ella han ido siempre vinculadas; y la soberbia actitud de triunfo sobre la realidad común o «vivida» que exhiben los creadores del arte «nuevo» ${ }^{34}$, son las razones del rechazo mayoritario que los espectadores manifiestan hacia el mismo. El distanciamiento de la realidad «vivida» y la representación de la realidad «contemplada» que acomete el arte contemporáneo es considerado por el público una tarea desprovista de dificultad y, por tanto, de interés. La causa de semejante razonamiento, señala Ortega, es la errónea vinculación por parte del público de los ámbitos o de las realidades propias de dos figuras tan distintas como el espectador y el artista. Al concebir su realidad «vivida» y la experiencia vital de ella resultante como algo necesariamente conectado con la realidad «contemplada» y la consiguiente experiencia estética desde la cual trabaja el creador, se contempla, juzga y exige a la abstracción metafórica del arte con los parámetros de un ámbito tan diferente como es el de la realidad concreta de la vida; se confunden vida y arte, el retratado y lo retratado, hombre y artista ${ }^{35}$.

32 Op. cit., pág. 49.

${ }^{33}$ Vid. Nota 4.

${ }^{34}$ Ortega considera lógica esta autosatisfacción del artista moderno frente a sus creaciones. «La "realidad" acecha constantemente al artista para impedir su evasión. ¡Cuánta astucia supone la fuga genial! Ha de ser un Ulises al revés, que se liberta de su Penélope cotidiana y entre escollos navega hacia la brujería de Circe. Cuando logra escapar un momento a la perpetua asechanza no llevemos a mal en el artista un gesto de soberbia, un breve gesto a lo San Jorge, con el dragón yugulado a los pies.» (Op. cit., pág. 65) Y, asimismo, considera que bajo esta arrogancia no hay sino una actitud honesta: «La aspiración al arte puro no es, como suele creerse, una soberbia, sino, por el contrario, gran modestia. Al vaciarse ele arte de patetismo humano queda si trascendencia alguna-como sólo arte, sin más pretensión.» (Op. cit., pág. 91)

${ }_{35}$ «Vida es una cosa, poesía es otra [...] No las mezclemos. El poeta empieza donde el hombre acaba. El destino de éste es vivir su itinerario humano; la misión de aquél es inventar lo que no existe. [...] El poeta aumenta el mundo, añadiendo a lo real, que ya está ahí por sí mismo, un irreal continente. Autor viene de auctor, el que aumenta.» Op. cit., pág. 72. 
De este error de base nacen todos los prejuicios con los que el público contemporáneo despreciará el arte de su época. El espectador queda perplejo ante unas representaciones deshumanizadas, es decir, ajenas a la realidad cotidiana que él habita; convencido de la igualdad entre hombre y artista e interpelado por una nueva obra de arte que exige para su comprensión la imaginación de nuevas realidades más abstractas, el espectador se instala en la postura del rechazo total del arte «nuevo». La razón más común dada para justificar semejante negación es afirmar que la creación de realidades distanciadas de la realidad «vivida» común y accesible a todos los hombres, entre los que sitúan a los artistas, es una tarea exenta de dificultad y carente de interés; sitúan el valor de la obra de arte en su proximidad respecto a la vida, en sus temas fácilmente identificables, y no en el distanciamiento en el que Ortega establece su sublimidad ${ }^{36}$. Esta actitud tan humana que es tomar la realidad como medida de todas las cosas -incluso de algo tan abstracto como las ideas ${ }^{37}$-, al estar reforzada en sus convicciones por la crítica de arte del momento ${ }^{38}$ así como por un arte «viejo» cuyas representaciones realistas y solemnes de las cosas materializan todas las pretensiones de realidad que el público posee como exigencias estéticas, parece revelarse como una verdad inamovible a partir de cuyo único prisma juzgar despiadadamente. Es por ello por lo que la broma y/o el carácter lúdico del arte «nuevo» serán acogidos con gran hostilidad, al interpretarse como un desacato intolerable a unos argumentos ba-

\footnotetext{
${ }^{36}$ «Cree el vulgo que es cosa fácil huir de la realidad, cuando es lo más difícil del mundo.[...] Pero lograr construir algo que no sea copia de lo "natural" y que, sin embargo, posea alguna substantividad, implica el don más sublime.» Op.cit., pág. 65.

37 «Pero es el caso que entre la idea y la cosa hay siempre una absoluta distancia. [...] Sin embargo, la tendencia natural nos lleva a creer que la realidad es lo que pensamos de ella, por tanto, a confundirla con la idea, tomando ésta de buena fe por la cosa misma. En suma, nuestro prurito vital de realismo nos hace caer en una ingenua idealización de lo real. Esta es la propensión nativa, "humana".» Op. cit., pág. 78

La tendencia «humana» de unir ámbitos tan diferenciados como el material (los objetos) y el intelectual (las ideas) en su aprehensión del mundo, estará continuamente presente, siempre bajo una fuerte ironía, en las obras del surrealista René Magritte así como en la producción filosófica de Michel Foucault, autor de la reflexión más lúcida realizada hasta el momento de la cuestión-su famoso Las palabras y las cosas- así como de un breve ensayo dedicado a una de las piezas más famosas del pintor surrealista (Esto no es una pipa. Ensayo sobre Magritte.)

${ }^{38}$ No olvidemos que el fenómeno de la aparición del público moderno estuvo acompañado por el nacimiento de la crítica de arte en medios de comunicación de masas como los periódicos. Tanto el público como la crítica estuvieron, y actualmente siguen estando, integrados por las mismas clases sociales, principalmente por una burguesía claramente predominante en todos los ámbitos desde el siglo XVIII. La actitud hostil de Ortega hacia esa burguesía mediocre en tanto portavoz de la «verdad» de unas opiniones sin fundamento fue diseccionada posteriormente en La rebelión de las masas pero puede ya intuirse en los ataques tanto al público como a la crítica de arte que constituye la prolongación de su voz en la opinión pública: «Los escritores que reducen su inspiración a expresar su estima o desestima por las obras de arte no deberían escribir. No sirven para este arduo menester» (Op. cit., pág. 62) puesto que alientan opiniones y descuidan una aproximación profunda y rigurosa a la problemática del arte «nuevo» y a la introducción que éste ha realizado de una nueva sensibilidad estética.
} 
sados en la incuestionable Tradición artística y en la seriedad profesional de un medio de expresión democrático y propiamente moderno como es la Crítica de $\mathrm{Arte}^{39}$. La seriedad con que se interpreta el arte «nuevo», al que se exige ser solemne y en cuyos artistas se buscan las figuras grandilocuentes y eternas que el Romanticismo instituyó como necesarios en el verdadero arte al crear a los genios, impide aproximarse a su visión irónica de la cosas, a la risa con que sí mismo se concibe ${ }^{40}$.

Pero, frente a estos argumentos que establecen que el rechazo del público por el arte «nuevo» procede de una lógica confusión fenomenológica, pues es de esperar que la mayoría de la población encuentre fuertes dificultades en distinguir entre abstracciones como realidad «vivida» y realidad «contemplada» ${ }^{41}$ Ortega introduce como principal causa de la impopularidad del arte «nuevo» un factor de tintes clasistas que explica las feroces críticas que han recibido tanto este ensayo como La rebelión de las masas. Pasemos a su análisis detallado, estudio que mostrará las necesidades de abordar dos obras más del pensador español para completar su lectura y significación.

El arte «nuevo» provoca la división, que pervive hoy en día, de sus espectadores en dos grupos radicalmente opuestos: sus partidarios, una minoría, y sus detractores, mucho más numerosos. La antipopularidad de los planteamientos de los que parten las nuevas propuestas estéticas es la explicación de su impopularidad. Pero lejos de permanecer inofensiva, esta clasificación esconde un criterio de

${ }^{39}$ Para una profundización mayor en el tema, véase CALVO SERRALLER, Francisco, Naturaleza y misión de la Crítica de Arte, Discurso para el ingreso en la Real Academia de Bellas Artes de San Fernando, Madrid, 2001.

40 «Al mismo tiempo se advierte ejemplarmente la dificultad del gran público para acomodar la visión a esta perspectiva invertida. Va buscando el drama humano que la obra constantemente desvirtúa, retira e ironiza, poniendo en su lugar-esto es, en primer plano-la ficción teatral misma, como tal ficción. Al gran público le irrita que le engañen y no sabe complacerse en el delicioso fraude del arte, tanto más exquisito cuanto mejor manifieste su textura fraudulenta.» Op. cit., págs. 79-80.

${ }^{41}$ De ahí que John Crispin considere más adecuado hablar de desfamiliarización que de deshumanización. En este sentido, el arte «nuevo» no es impopular por deshumanizar o alejar sus representaciones de la realidad humana común sino por introducir la necesidad en el espectador de alejarse de lo por él conocido, de la realidad a la que está familiarizado.

«La palabra 'deshumanización' nace, pues, de un latente prejuicio de Ortega, convencido de la incapacidad del ser humano medio de lograr la distancia necesaria para apreciar el arte como logro creativo y no como instrumento de convivencia. (...) La llamada 'deshumanización es un proceso por el cual es espectador debe llegar a un máximum de distancia, y a un mínimum de intervención sentimental o vital. La obra de arte, especialmente según la estética de la época, debe 'desfamiliarizar', según el término del formalismo ruso, cualquier asunto conocido y obligarnos a reconstruirlo bajo otro plano.» CRISPIN, John, La estética de las generaciones de 1925, Valencia, Pre-Textos, 2002, págs. 69 y 71.

Como puede observarse, frente al drástico y elitista análisis de Ortega, la lectura de Crispin introduce la posibilidad de una aproximación - y futuro deleite - por parte de la masa no docta al arte contemporáneo, arte que en tanto no familiar, es decir, no asimilado por la fuerza de la costumbre, puede volverse cercano a fuerza del contacto con él. 
selección social e intelectual ${ }^{42}$ : el arte «nuevo» remarca la condición o naturaleza de cada uno de los grupos que genera. La experiencia estética inteligente perseguida por sus obras es contraria por naturaleza al recurso fácil, al efectismo o a los medios de comunicación masivos o, según palabras del pensador, «contagiosos» ${ }^{43}$. Su desapego de la realidad «vivida», su abstracción y la ironía con la que se construye implica para su comprensión cierta inteligencia por parte del espectador; de ahí que el partidario del arte «nuevo» se halle en posesión de ciertos conocimientos o de la sensibilidad propia de los artistas, es decir, extraña a la mayoría de los seres humanos ${ }^{44}$. «Lo característico del arte nuevo, "desde el punto de vista sociológico", es que divide al público en estas dos clases de hombres: los que lo entienden y los que no lo entienden ${ }^{45}$, los que lo aceptan y los que lo rechazan. Los hombres quedan, de este modo, drásticamente divididos.

El primer tipo de hombre, un espectador minoritario que es calificado como espectador inteligente, obtiene de su experiencia estética un placer verdadero en tanto que justificado: puesto que conoce y entiende la obra a la que se enfrenta, su alegría tiene tanto una causa - semejante comprensión - como un motivo - el ser consciente de que el objeto de su regocijo es la contemplación cultivada de la obra de arte- . El espectador inteligente sabe jugar, apuesta y, en su arriesgarse, obtiene el premio de la experiencia estética ${ }^{46}$.

42 «Actúa, pues, la obra de arte como un poder social que crea dos grupos antagónicos, que separa y selecciona en el montón informe de la muchedumbre dos castas diferentes de hombres.» ORTEGA Y GASSET, José, La deshumanización del arte y otros ensayos de estética, Madrid, Austral, 2004, pág. 49. Obsérvese el empleo del término «casta» para referirse a los grupos que genera el arte «nuevo».

Puesto que casta, según lo recoge el Diccionario de la Real Academia de la Lengua Española, significa «generación o linaje» así como «parte de los habitantes de un país que forma clase especial, sin mezclarse con las demás, unas veces por considerarse privilegiada y otras por miserable y abatida», las connotaciones de selección o diferenciación quedan más que evidentes.

${ }^{43}$ Así es como califica Ortega a los recursos artísticos que logran difundir y popularizar entre la gran mayoría de los espectadores el estilo del que son parte. El pensador español señala el Romanticismo como paradigma del empleo de estos recursos de «propagación» fácil: el sentimentalismo exacerbado de compositores como Wagner o la representación de la realidad «vivida» común por parte de tendencias como el Realismo son algunos de los ejemplos en los que está pensando. La hostilidad hacia el Romanticismo y su eclosión afectiva fue un rasgo común a unas «Generaciones de 1925» que buscaron distanciarse de la etapa anterior en su nuevos planteamientos artísticos. En Ortega, asimismo, este rechazo responde a su crítica de las masas, indiscutiblemente protagonistas de todo el desarrollo del siglo XIX.

44 «Y en este proceso se llegará a un punto en que el contenido humano de la obra sea tan escaso que casi no se le vea. Entonces tendremos un objeto que sólo puede ser percibido por quien posea ese don peculiar de la sensibilidad artística. Será un arte para artistas, y no para la masa de los hombres; será un arte de casta, y no demótico.» Op. cit., pág. 55.

45 Op. cit., pág. 50.

${ }^{46}$ Ortega compara el placer que obtiene el partidario/conocedor del arte «nuevo» de la contemplación estética con el de un premiado por la Lotería: «El regocijo del premiado, en cambio, consiste precisamente en darse cuenta de un hecho que lo motiva y lo justifica. Se regocija porque ve un objeto en sí mismo regocijante. Es una alegría con ojos, que vive de su motivación y parece fluir del objeto hacia el sujeto.» Op. cit., pág. 69. 
En contraposición al espectador inteligente se halla el segundo tipo de hombre, el detractor de las nuevas manifestaciones artísticas, el denominado espectador «contagioso». Si el espectador inteligente era comparado al premiado en un juego de azar, en este caso el espectador «contagioso» aparece representado por la figura del borracho. Al igual que el premiado, el espectador borracho obtiene de la contemplación estética placer, pero esta alegría, en tanto causada por algo ajeno a él y a su conocimiento —el alcohol-, es falsa. La contemplación que el borracho realiza de la obra de arte no ve más allá de las apariencias de ésta, es la aproximación ciega y fugaz propia de la ebriedad; y la alegría alcohólica derivada de ésta - fugaz, ilusoria - no tiene motivo o fundamento alguno. Es un placer ciego y no perspicaz $^{47}$.

No vamos a negar aquí la drástica separación que hace Ortega entre hombres conocedores y hombres no conocedores del arte contemporáneo, entre «hombres egregios» y «hombres vulgares» ${ }^{48}$, distinción que está presente en otros ensayos del autor dedicados a cuestiones estéticas ${ }^{49}$. Pero queremos señalar que esta crítica feroz se refiere más a algo adquirido que a algo innato en el hombre. En La deshumanización del arte, Ortega pretende ante todo «invitar a comprender» ${ }^{50}$, es decir, evitar que el público se mueva por la ceguera de los prejuicios adquiridos y condene el arte »nuevo" sin un previo entendimiento de la cuestión; y lo interesante es que él mismo se incluye en esta advertencia ${ }^{51}$. Ortega es consciente de la ardua tarea que es despojarse de los prejuicios a partir de los cuales, inevitablemente, hemos conformado nuestra visión del mundo ${ }^{52}$, pero es absolutamente

47 «La alegría del borracho es ciega; tiene, como todo en el mundo, su causa: el alcohol, pero carece de motivo. El favorecido con un premio de la Lotería también se alegra, pero con una alegría muy diferente; se alegra "de" algo determinado. La jocundia del borracho es hermética, está encerrada en sí misma, no sabe de donde viene y, como suele decirse, "carece de fundamento".» Ibidem.

48 Op. cit., pág. 51.

${ }^{49}$ En el artículo «Musicalia» aparecido en el número III de El Espectador(1921), Ortega analiza semejante problemática a partir del rechazo generalizado que muestra el público hacia las creaciones de Claude Debussy. ORTEGA Y GASSET, José, Obras completas, 2005, tomo II, págs. 365-374.

${ }^{50}$ Nombre de uno de los apartados del ensayo. ORTEGA Y GASSET, José, La deshumanización del arte y otros ensayos de estética, pág. 69.

51 «Me ha movido exclusivamente la delicia de intentar comprender —ni la ira ni el entusiasmo- . He procurado buscar el sentido de los nuevos propósitos artísticos, y esto, claro es, supone un estado de espíritu lleno de previa benevolencia. Pero ¿es posible acercarse de otra manera a un tema sin condenarlo a la esterilidad?» Op. cit., pág. 92.

${ }^{52}$ Ya desde Platón encontramos la diferenciación entre episteme (ciencia) y doxa (opinión) en la adquisición del conocimiento: mientras la episteme o ciencia es aquello que conocemos por que lo hemos comprobado por nosotros mismos, doxa u opinión es aquello que conocemos por que nos lo han comunicado. Semejante división, origen del conocimiento verdadero y falso, respectivamente, muestra que la mayor parte de nuestros conocimientos proceden de fuera de nuestra misma experiencia cognitiva y que, por tanto, pueden ser, y son, prejuicios. La imposibilidad manifiesta de adquirir todos los conocimientos de forma directa ha hecho que de un tiempo a esta parte la teoría del conocimiento o epistemología sea considerada una doxastología. 
contrario al progresivo triunfo de las opiniones que desde la Declaración de los derechos del hombre y del ciudadano de 1789 inunda Europa en todos sus ámbitos. Semejante preocupación es mencionada en La deshumanización del arte por el pensador cuando afirma que «La unidad indiferenciada, caótica, informe, sin arquitectura anatómica, sin disciplina regente en que se ha vivido por espacio de ciento cincuenta años no puede continuar. Bajo toda la vida contemporánea late una injusticia profunda e irritante: el falso supuesto de la igualdad real entre los hombres " ${ }^{53}$. Pero, es en La rebelión de las masas donde el autor abordará de manera magistral esta problemática.

${ }^{53}$ Op. cit., pág. 51. 